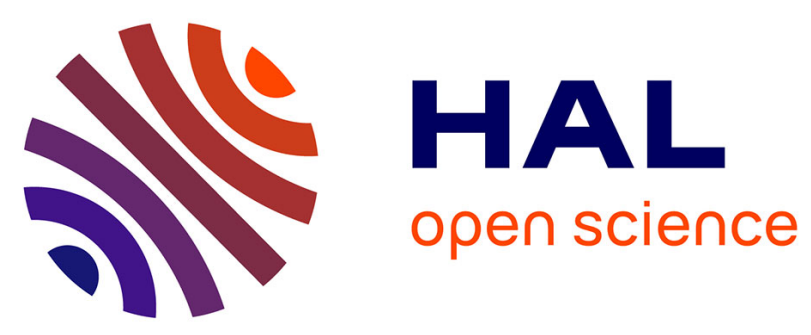

\title{
Insulin-independent effects of GLP-1 on canine liver glucose metabolism: Duration of infusion and involvement of hepatoportal region
}

Dominique Dardevet, Mary Courtney Moore, Doss Neal, Catherine A. Di Costanzo, Wanda Snead, Alan D. Cherrington

\section{To cite this version:}

Dominique Dardevet, Mary Courtney Moore, Doss Neal, Catherine A. Di Costanzo, Wanda Snead, et al.. Insulin-independent effects of GLP-1 on canine liver glucose metabolism : Duration of infusion and involvement of hepatoportal region. AJP - Endocrinology and Metabolism, 2004, 287 (1), pp.E75-E81. 10.1152/ajpendo.00035.2004 . hal-02682832

\section{HAL Id: hal-02682832 \\ https://hal.inrae.fr/hal-02682832}

Submitted on 1 Jun 2020

HAL is a multi-disciplinary open access archive for the deposit and dissemination of scientific research documents, whether they are published or not. The documents may come from teaching and research institutions in France or abroad, or from public or private research centers.
L'archive ouverte pluridisciplinaire HAL, est destinée au dépôt et à la diffusion de documents scientifiques de niveau recherche, publiés ou non, émanant des établissements d'enseignement et de recherche français ou étrangers, des laboratoires publics ou privés. 


\section{Dardevet, M. C. Moore, D. Neal, C. A. DiCostanzo, W. Snead and A. D. Cherrington \\ Am J Physiol Endocrinol Metab 287:75-81, 2004. First published Mar 16, 2004; \\ doi:10.1152/ajpendo.00035.2004}

You might find this additional information useful...

This article cites 44 articles, 26 of which you can access free at:

http://ajpendo.physiology.org/cgi/content/full/287/1/E75\#BIBL

This article has been cited by 12 other HighWire hosted articles, the first 5 are:

Effect of Endogenous GLP-1 on Insulin Secretion in Type 2 Diabetes

M. Salehi, B. Aulinger, R. L. Prigeon and D. A. D'Alessio

Diabetes, June 1, 2010; 59 (6): 1330-1337.

[Abstract] [Full Text] [PDF]

Portal glucose infusion-glucose clamp measures hepatic influence on postprandial systemic glucose appearance as well as whole body glucose disposal

D. Zheng, V. Ionut, V. Mooradian, D. Stefanovski and R. N. Bergman

Am J Physiol Endocrinol Metab, February 1, 2010; 298 (2): E346-E353.

[Abstract] [Full Text] [PDF]

Inhibition of Dipeptidyl Peptidase-4 by Vildagliptin During Glucagon-Like Peptide 1

Infusion Increases Liver Glucose Uptake in the Conscious Dog

D. S. Edgerton, K. M.S. Johnson, D. W. Neal, M. Scott, C. H. Hobbs, X. Zhang, A. Duttaroy and

A. D. Cherrington

Diabetes, January 1, 2009; 58 (1): 243-249.

[Abstract] [Full Text] [PDF]

Portal infusion of amino acids is more efficient than peripheral infusion in stimulating liver protein synthesis at the same hepatic amino acid load in dogs

D. Dardevet, S. R Kimball, L. S Jefferson, A. D Cherrington, D. Remond, C. A DiCostanzo and

M. C. Moore

Am. J. Clinical Nutrition, October 1, 2008; 88 (4): 986-996.

[Abstract] [Full Text] [PDF]

\section{Role of Central Nervous System Glucagon-Like Peptide-1 Receptors in Enteric Glucose} Sensing

C. Knauf, P. D. Cani, D.-H. Kim, M. A. Iglesias, C. Chabo, A. Waget, A. Colom, S. Rastrelli, N. M. Delzenne, D. J. Drucker, R. J. Seeley and R. Burcelin

Diabetes, October 1, 2008; 57 (10): 2603-2612.

[Abstract] [Full Text] [PDF]

Updated information and services including high-resolution figures, can be found at:

http://ajpendo.physiology.org/cgi/content/full/287/1/E75

Additional material and information about AJP - Endocrinology and Metabolism can be found at: http://www.the-aps.org/publications/ajpendo

This information is current as of September 3, 2010 .

AJP - Endocrinology and Metabolism publishes results of original studies about endocrine and metabolic systems on any level of organization. It is published 12 times a year (monthly) by the American Physiological Society, 9650 Rockville Pike, Bethesda MD 20814-3991. Copyright @) 2004 by the American Physiological Society. ISSN: 0193-1849, ESSN: 1522-1555. Visit our website at http://www.the-aps.org/. 


\title{
Insulin-independent effects of GLP-1 on canine liver glucose metabolism: duration of infusion and involvement of hepatoportal region
}

\author{
D. Dardevet, ${ }^{1,2}$ M. C. Moore, ${ }^{1}$ D. Neal, ${ }^{1}$ C. A. DiCostanzo, ${ }^{1}$ W. Snead, ${ }^{1}$ and A. D. Cherrington ${ }^{1}$ \\ ${ }^{1}$ Department of Molecular Physiology and Biophysics, Vanderbilt University School of Medicine, \\ Nashville, TN 37232; and ${ }^{2}$ Unité de Nutrition et Métabolisme Protéique, Institut National de la \\ Recherche Agronomique, Centre de Recherches en Nutrition Humaine de Clermont-Fd, 63122 Ceyrat, France
}

Submitted 26 January 2004; accepted in final form 9 March 2004

\begin{abstract}
Dardevet, D., M. C. Moore, D. Neal, C. A. DiCostanzo, W. Snead, and A. D. Cherrington. Insulin-independent effects of GLP-1 on canine liver glucose metabolism: duration of infusion and involvement of hepatoportal region. Am J Physiol Endocrinol Metab 287: E75-E81, 2004. First published March 16, 2004; 10.1152/ ajpendo.00035.2004.-Whether glucagon-like peptide-1 (GLP-1) has insulin-independent effects on glucose disposal in vivo was assessed in conscious dogs by use of tracer and arteriovenous difference techniques. After a basal period, each experiment consisted of three periods (P1, P2, P3) during which somatostatin, glucagon, insulin, and glucose were infused. The control group $(\mathrm{C})$ received saline in P1, P2, and $\mathrm{P} 3$, the PePe group received saline in P1 and GLP-1 (7.5 $\mathrm{pmol} \cdot \mathrm{kg}^{-1} \cdot \mathrm{min}^{-1}$ ) peripherally (Pe; iv) in P2 and P3, and the PePo group received saline in P1 and GLP-1 peripherally (iv) (P2) and then into the portal vein (Po; P3). Glucose and insulin concentrations increased to two- and fourfold basal, respectively, and glucagon remained basal. GLP-1 levels increased similarly in the PePe and PePo groups during P2 ( $200 \mathrm{pM})$, whereas portal GLP-1 levels were significantly increased (3-fold) in PePo vs. PePe during P3. In all groups, net hepatic glucose uptake (NHGU) occurred during P1. During P2, NHGU increased slightly but not significantly in all groups. During P3, NHGU increased in PePe and PePo groups to a greater extent than in $\mathrm{C}$, but no significant effect of the route of infusion of GLP-1 was demonstrated $(16.61 \pm 2.91$ and $14.67 \pm 2.09$ vs. $4.22 \pm 1.57 \mu \mathrm{mol} \cdot \mathrm{kg}^{-1} \cdot \mathrm{min}^{-1}$, respectively). In conclusion: GLP-1 increased glucose disposal in the liver independently of insulin secretion; its full action required long-term infusion. The route of infusion did not modify the hepatic response.
\end{abstract}

glucagon-like peptide-1; glucose uptake; portal infusion; dog

GLUCAGON-LIKE PEPTIDE-1 (GLP-1) is synthesized from proglucagon in the L cells of the duodenum, distal ileum, and colon in response to meal absorption, after which it is rapidly released into the portal vein $(22,37)$. The main and active form of GLP-1, GLP-1-(7-36), is rapidly degraded by dipeptidyl peptidase IV (DPP-IV) into GLP-1-(9-36) in the intestinal tissues as well as in the blood $(23,27)$. The consequence is a rapid elimination of GLP-1 from plasma with a half-life estimated at 1-2 min in several species (22). The earliest biological effect of GLP-1 discovered was its ability to increase glucose-dependent insulin secretion $(18,28)$ as well as the transcription of the proinsulin gene and biosynthesis of insulin (12). The glucose-dependent effect of GLP-1 on insulin secretion has suggested a potential use of this agent in the treatment of diabetes without deleterious hypoglycemia. Indeed, it lowers postprandial glucose levels in both healthy and human subjects

Address for reprint requests and other correspondence: D. Dardevet, 702 Light Hall, Vanderbilt Univ. School of Medicine, Nashville, TN 37232-0615 (E-mail: Dominique.P.Dardevet@vanderbilt.edu). with type 2 diabetes by stimulating insulin secretion but also by inhibiting glucagon secretion from the $\alpha$-cell and delaying gastric emptying $(1,17,40)$.

GLP-1 receptors are present on $\beta$-cells (38), and there are numerous reports of GLP-1 receptors on glucose-consuming tissues such as liver, skeletal muscle and fat $(11,39,42)$. Most in vitro studies show that GLP-1 stimulates glucose uptake and metabolism in muscle $(24,41,44)$, adipocytes $(20,43)$, and hepatocytes (2) and that GLP-1 can potentially promote glucose disposal directly, in addition to its effect on insulin secretion. In vivo, GLP-1's insulin secretion-independent effects are much less clear. Some data are in agreement with a GLP-1 effect independent of insulin secretion $(8-10,15)$ whereas others exclude such an action $(8,33,34)$. In addition to the species differences, these investigations have been performed with different levels of insulin or glucose and with acute or chronic GLP-1 delivery into the systemic circulation.

GLP-1 concentrations are physiologically increased during the postprandial phase, and its direct tissue effects may require the presence of insulin and/or hyperglycemia to be fully manifested. Furthermore, GLP-1 is secreted into the hepatic portal vein, and recent evidence suggests the presence of GLP-1 sensors or receptors in the hepatoportal region $(5,30,32)$. Because of the rapid degradation of GLP-1 in the plasma, the hepatoportal region may play a critical role in the generation of the full effects of GLP-1. Because of these considerations, a recent study was conducted in our laboratory (31), in which the effect of various rates of portal GLP-1 infusion was sequentially studied under conditions of controlled hyperinsulinemia and hyperglycemia in the conscious dog. The results showed that GLP-1 has an effect independent of its action on insulin secretion. However, despite an apparent dose-dependent effect of GLP-1, the study design raised the possibility that GLP-1 may also have a time-dependent effect. We performed the present studies in the conscious dog model to assess the time-dependent effect of GLP-1 on hepatic and nonhepatic glucose metabolism under conditions that mimic the postprandial state (hyperglycemia and hyperinsulinemia).

We used the fasted conscious dog as our model because it provides a good reflection of glucose metabolism in humans and because it has the advantage of allowing invasive experimental design, which facilitates the performance of mechanistic studies in vivo (7). Furthermore, it is clear that GLP-1 levels in plasma were increased in the dog after an intragastric glucose load to levels similar to those recorded in humans and

The costs of publication of this article were defrayed in part by the payment of page charges. The article must therefore be hereby marked "advertisement" in accordance with 18 U.S.C. Section 1734 solely to indicate this fact. 
Table 1. Hepatic blood flows and plasma insulin, glucagon, and GLP-1 concentrations in 42-h-fasted dogs under basal conditions and during infusion of somatostatin, intraportal insulin, and glucagon and peripheral glucose

\begin{tabular}{|c|c|c|c|c|c|c|c|c|c|c|c|c|}
\hline & \multicolumn{3}{|c|}{ Basal } & \multicolumn{3}{|c|}{$\mathrm{P} 1$} & \multicolumn{3}{|c|}{$\mathrm{P} 2$} & \multicolumn{3}{|c|}{ P3 } \\
\hline $\begin{array}{l}\text { Hepatic arterial } \\
\text { flow }\end{array}$ & 6.2 & 5.6 & 4.9 & $7.3^{*}$ & $7.8^{*}$ & 5.6 & $8.1 *$ & $8.7^{*}$ & $6.1^{*}$ & $9.4 *$ & $8.9 *$ & $7.3^{*}$ \\
\hline \multirow[t]{2}{*}{ Portal vein flow } & 27.5 & 28.6 & 27.3 & 22.1 & 23.2 & 21.1 & 21.92 & 22.6 & 20.5 & 21.5 & 22.6 & 20.7 \\
\hline & \pm 2.3 & \pm 3.1 & \pm 2.8 & \pm 2.4 & \pm 2.9 & \pm 1.7 & \pm 2.20 & \pm 3.1 & \pm 1.7 & \pm 2.2 & \pm 3.1 & \pm 1.7 \\
\hline \multirow{2}{*}{$\begin{array}{l}\text { Total hepatic } \\
\text { blood flow }\end{array}$} & 33.7 & 34.2 & 32.2 & 29.5 & 31.0 & 26.8 & 29.9 & 31.4 & 26.7 & 31.0 & 31.6 & 28.0 \\
\hline & \pm 2.4 & \pm 3.2 & \pm 2.8 & \pm 2.6 & \pm 3.0 & \pm 1.9 & \pm 2.6 & \pm 2.9 & \pm 1.7 & \pm 2.7 & \pm 3.0 & \pm 1.5 \\
\hline \multirow{2}{*}{$\begin{array}{l}\text { Hepatic sinusoidal } \\
\text { insulin }\end{array}$} & 19.2 & 18.0 & 15.2 & $70.3^{*}$ & $78.1^{*}$ & $73.8^{*}$ & $76.7^{*}$ & $77.9^{*}$ & $71.0 *$ & $76.4^{*}$ & $78.1^{*}$ & $70.0^{*}$ \\
\hline & \pm 3.7 & \pm 2.3 & \pm 1.1 & \pm 5.1 & \pm 6.7 & \pm 4.8 & \pm 6.7 & \pm 5.3 & \pm 7.8 & \pm 7.1 & \pm 6.6 & \pm 7.1 \\
\hline \multirow[t]{2}{*}{ Arterial glucagon } & 47.8 & 46.7 & 42.9 & 41.4 & 44.8 & 42.1 & 38.7 & 36.7 & 38.5 & 40.1 & 34.7 & 37.5 \\
\hline & \pm 3.6 & \pm 7.7 & \pm 5.7 & \pm 5.2 & \pm 3.4 & \pm 3.1 & \pm 2.8 & \pm 5.3 & \pm 3.5 & \pm 3.5 & \pm 3.5 & \pm 2.4 \\
\hline \multirow{2}{*}{$\begin{array}{l}\text { Hepatic sinusoidal } \\
\text { glucagon }\end{array}$} & 45.2 & 54.2 & 50.2 & 50.3 & 47.5 & 55.5 & 50.5 & 45.8 & 52.5 & 48.3 & 45.2 & 48.6 \\
\hline & \pm 2.3 & \pm 6.6 & \pm 4.5 & \pm 1.4 & \pm 6.1 & \pm 3.3 & \pm 2.7 & \pm 3.7 & \pm 2.1 & \pm 3.4 & \pm 5.7 & \pm 3.7 \\
\hline
\end{tabular}

Data are means $\pm \mathrm{SE} ; n=6$. P1, 120-210 min; P2, 210-300 min; P3, 300-390 min. Glucagon-like peptide-1 (GLP-1) was infused peripherally during P2 and P3 (PePe group) and peripherally during P2 and intraportally during P3 (PePo group). $* P<0.05$ vs. basal period; $\uparrow P<0.05$ vs. PePe; ND, not determined.

effects recorded will thus be independent of the GLP-1 effect on insulin and glucagon secretion. Arterial blood flows increased slightly with time, but no significant differences were recorded among groups. Portal blood flows tended to decrease after the basal period due to somatostatin infusion. Total hepatic blood flow therefore changed minimally $(<10 \%)$ in all groups over the course of the study.

With the peripheral (iv) GLP-1 infusion, arterial and portal GLP-1 concentrations increased significantly and reached supraphysiological levels $(\approx 200 \mathrm{pM}$; Table 1$)$. These levels remained constant with time in the PePe group. In the PePo group, arterial and portal GLP-1 levels increased to the same extent as those in the PePe group during P2, but portal GLP-1 concentrations dramatically increased $(\approx 500 \mathrm{pM})$ with the start of the portal infusion of GLP-1 (P3). Interestingly, arterial GLP-1 concentrations were only slightly lower with portal vein GLP-1 infusion than with peripheral GLP-1 infusion (Table 1).

Blood glucose levels and hepatic glucose balance. In response to peripheral glucose infusion, arterial blood glucose increased significantly in all groups from $\approx 6$ to $\approx 12.5 \mathrm{mM}$. The hepatic glucose loads during the basal period were $150 \pm$ $11,151 \pm 13$, and $135 \pm 12 \mu \mathrm{mol} \cdot \mathrm{kg}^{-1} \cdot \mathrm{min}^{-1}$ in Control, $\mathrm{PePe}$, and PePo groups, respectively. In response to the glucose infusion, hepatic glucose loads increased significantly and similarly in all groups and then remained constant over time (P1: $261 \pm 22,260 \pm 21$, and $237 \pm 14 ; \mathrm{P} 2: 272 \pm 23,265 \pm$ 20, and $244 \pm 11$; and P3: $277 \pm 23,266 \pm 20$, and $251 \pm 10$ $\mathrm{mg} \cdot \mathrm{kg}^{-1} \cdot \mathrm{min}^{-1}$ in Control, PePe, and PePo groups, respectively). The combination of hyperinsulinemia and hyperglycemia during the P1 test period switched the liver from net hepatic glucose output to NHGU in all groups (data not shown). During saline infusion, NHGU increased slightly (over P1) during P2 and P3 $[\Delta=0.16 \pm 1.53$ and $4.22 \pm 1.57$ (not significant, NS), respectively; Fig. 2A]. Peripheral infusion of GLP-1 did not enhance NHGU during P2 (relative to P1), but it stimulated NHGU $\left(\approx 3\right.$-fold: $\left.16.61 \pm 2.91 \mu \mathrm{mol} \cdot \mathrm{kg}^{-1} \cdot \mathrm{min}^{-1}\right)$ after more prolonged infusion (P3). The route of GLP-1 infusion made no difference in its ability to increase NHGU in P3 (14.67 \pm $2.09 \mu \mathrm{mol} \cdot \mathrm{kg}^{-1} \cdot \mathrm{min}^{-1}$; Fig. $2 A$ ).

The FE of glucose followed the same pattern as NHGU (Fig. $2 B)$. Short-term peripheral GLP-1 infusions did not increase FE significantly, whereas prolonged GLP-1 infusions did. Nevertheless, peripheral and portal GLP-1 infusions resulted in the same increase $(\Delta=1.5 \pm 1.0,6.4 \pm 1.3$, and $5.1 \pm 0.9 \%$ for $\mathrm{C}, \mathrm{PePe}$, and PePo during $\mathrm{P} 3$ relative to $\mathrm{P} 1$, respectively; Fig. 2B).

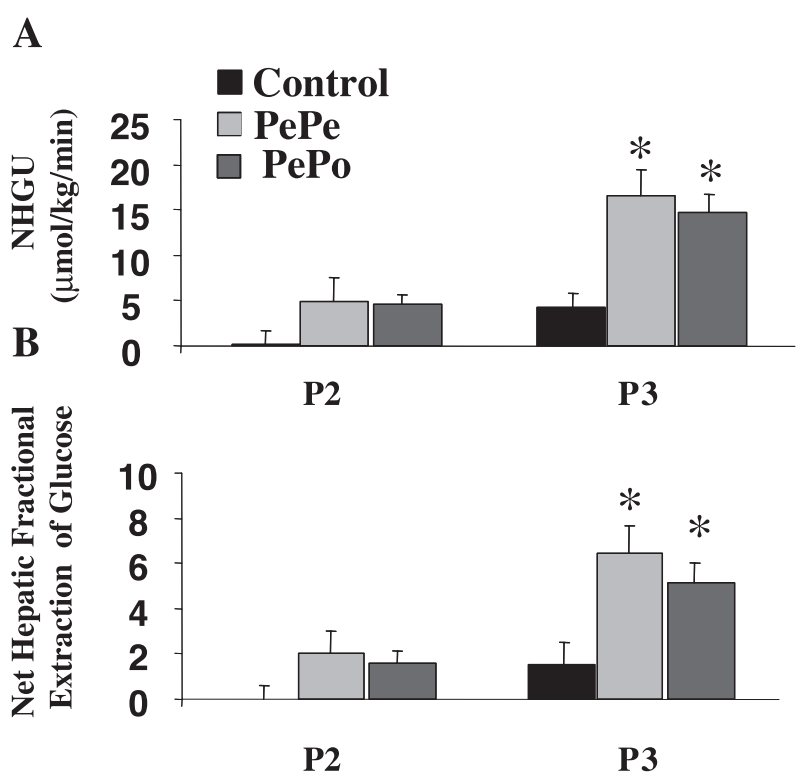

Fig. 2. GLP-1 effects on net hepatic glucose uptake (NHGU; $A$ ) and net hepatic fractional extraction $(B)$ in 42 -h-fasted dogs in the presence of somatostatin, intraportal insulin and glucagon, and peripheral glucose infusions. GLP-1 was infused peripherally during $\mathrm{P} 2$ and $\mathrm{P} 3$ (PePe group) and peripherally during P2 and intraportally during P3 (PePo group). Data are expressed as means $\pm \mathrm{SE}$ $(n=6)$ and represent incremental increase of NHGU and FE over insulin period P1. ${ }^{*} P<0.05$ vs. Control group. 
The mean GIR required to maintain constant hyperglycemia increased significantly over the experimental periods (Fig. 3). However, no differences between groups were recorded in any test period. When assessed with the tracer dilution technique, the whole body glucose utilization $\left(\mathrm{R}_{\mathrm{d}}\right)$ followed the same pattern as the GIR (Fig. 3). $R_{d}$ increased with time in each experimental group, but no differences were recorded between groups at any time point. The nonhepatic glucose uptake (non-HGU) was the same in all groups in P1 $(28.5 \pm 2.9$, $27.6 \pm 4.3$, and $26.1 \pm 4.8 \mu \mathrm{mol} \cdot \mathrm{kg}^{-1} \cdot \mathrm{min}^{-1}$ for $\mathrm{C}$, PePe, and PePo, respectively). During P2, non-HGU increased significantly in each experimental group $(40.9 \pm 3.7,39.7 \pm 3.1$, and $43.2 \pm 8.2 \mu \mathrm{mol} \cdot \mathrm{kg}^{-1} \cdot \mathrm{min}^{-1}$ for $\mathrm{C}, \mathrm{PePe}$, and PePo, respectively), with no significant difference among groups. During P3, after the prolonged peripheral or intraportal GLP-1 infusions, non-HGU was not significantly different from the values recorded in $\mathrm{P} 2$.

Lactate concentrations and net hepatic lactate and glycogen synthesis. After initiating the hyperglycemic hyperinsulinemic clamp, arterial blood lactate concentrations increased and remained constant during all of the test periods P1, P2 and P3 (from $\approx 0.6$ to $1.0 \mathrm{mM}$ ), with no significant differences among groups (not shown). Net hepatic lactate balance (NHLB) changed from uptake to output in all groups, and after a peak during P1 it declined to a value not significantly different from $0 \mu \mathrm{mol} \cdot \mathrm{kg}^{-1} \cdot \mathrm{min}^{-1}$ in all groups during P2 and P3 (Fig. 4). Concomitantly, P1 was associated with NHCR (data not shown). During the peripheral GLP-1 infusion (P2), NHCR was significantly stimulated over $\mathrm{P} 1$ in $\mathrm{PePe}$ and PePo groups compared with $\mathrm{C}(\Delta=1.0 \pm 1.8,6.6 \pm 2.2$, and $8.6 \pm 0.6$ $\mu \mathrm{mol} \cdot \mathrm{kg}^{-1} \cdot \mathrm{min}^{-1}$ for $\mathrm{C}, \mathrm{PePe}$, and PePo, respectively; Fig. 4). With prolonged GLP-1 infusion (P3), NHCR further increased and was significantly higher in the PePe and PePo groups $(\Delta=5.1 \pm 1.4,16.2 \pm 2.7$, and $18.5 \pm 1.3$ $\mu \mathrm{mol} \cdot \mathrm{kg}^{-1} \cdot \mathrm{min}^{-1}$ for $\mathrm{C}, \mathrm{PePe}$, and PePo, respectively; $P<$ 0.05 vs. P1 for all groups; $P>0.05$ for PePe vs. PePo; Fig. 4).

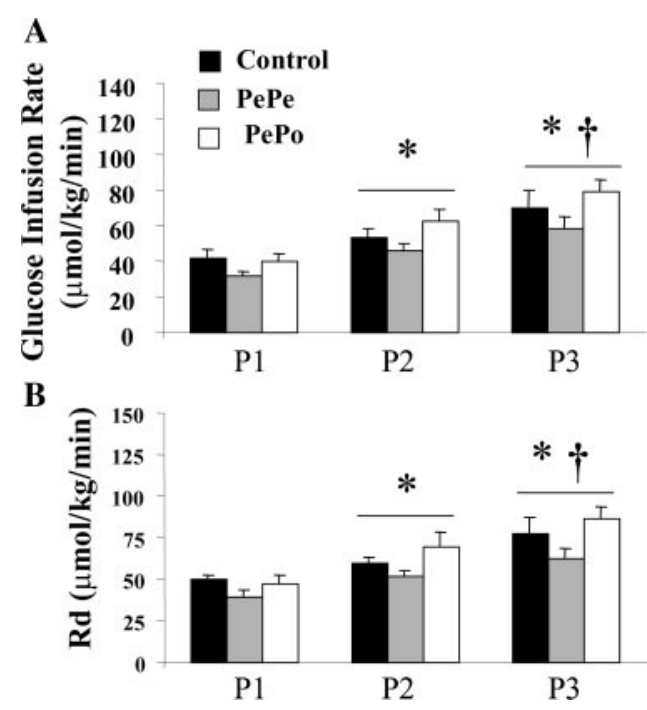

Fig. 3. GLP-1 effects on glucose infusion rate $(A)$ and whole body glucose utilization $\left(\mathrm{R}_{\mathrm{d}} ; B\right)$ in 42-h-fasted dogs in the presence of somatostatin, intraportal insulin and glucagon, and peripheral glucose infusions. GLP-1 was infused peripherally during P2 and P3 (PePe group) and peripherally during P2 and intraportally during P3 (PePo group). Data are expressed as means $\pm \mathrm{SE}$ ( $n=6$ ) for each test period. $* P<0.05$ vs. $\mathrm{P} 1 ; \dagger P<0.05$ vs. P2.
A

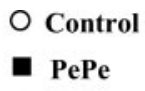

$\triangle$ PePo

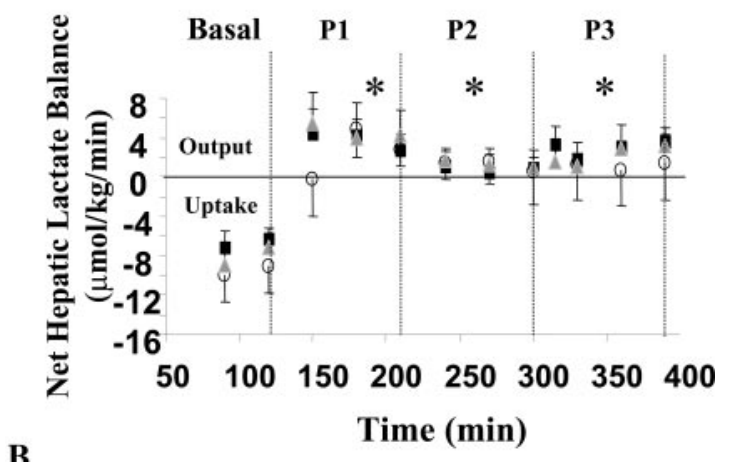

B

Fig. 4. Net hepatic lactate balance $(A)$ and net hepatic carbon retention $(B)$ in 42-h-fasted dogs in the presence of somatostatin, intraportal insulin and glucagon, and peripheral glucose infusions. GLP-1 was infused peripherally during P2 and P3 (PePe group) and peripherally during P2 and intraportally during P3 (PePo group). Data are expressed as means \pm SE $(n=6)$ for each test period. GE, glucose equivalent. $* P<0.05$ vs. Basal period; $* * P<0.05$ vs. Control group.

\section{DISCUSSION}

Previous work performed in our laboratory (31) had shown that GLP-1 is able to increase glucose disposal independently of its well-recognized effects on insulin and glucagon secretion. Furthermore, the results had suggested that the insulin secretion-independent effects of GLP-1 were dose dependent, but the design of the study had left open the possibility of a time-dependent effect of GLP-1, i.e., that prolonged infusions might be required to observe the full effects of the hormone. If so, the sensitivity of these processes to GLP-1 might be much greater than what was indicated in that study. The present study was carried out to examine this issue. Furthermore, in light of the recent suggestion that GLP-1 receptors in the portal vein might play an important physiological role $(5,30,32)$, the potential involvement of the hepatoportal region in the mechanism of action of GLP-1 was assessed by comparing peripheral and intraportal infusions of GLP-1.

In the current study, GLP-1 was infused at a rate of 7.5 $\mathrm{pmol} \cdot \mathrm{kg}^{-1} \cdot \mathrm{min}^{-1}$ to achieve modest pharmacological arterial GLP-1 concentrations. This rate, based on the study of Nishizawa et al. (31), was chosen to increase GLP-1 concentrations enough to observe maximal effects of the peptide. In the present study, GLP- 1 concentrations reached $\approx 200 \mathrm{pM}$ in the arterial plasma and went up to $\approx 500 \mathrm{pM}$ in the portal vein when GLP-1 was infused intraportally. Based on the literature 
(25), the physiological arterial level of GLP-1 following an oral glucose load $(2 \mathrm{~g} / \mathrm{kg})$ or mixed meal in dogs is $20 \mathrm{pM}$. Because of the difference between the assays or antibodies used in the determination of GLP-1, we measured (using the same assay as for our present experiment) intact arterial and portal GLP-1 concentrations in four overnight-fasted dogs under basal conditions and following an intragastric glucose load of $1.5 \mathrm{~g} / \mathrm{kg}$ (unpublished data). The basal levels were $\approx 17$ pM in both artery and portal vein. After the glucose bolus, GLP-1 levels peaked at $\approx 40 \mathrm{pM}$ in the artery and $\approx 65 \mathrm{pM}$ in the portal vein. On the basis of these data, GLP-1 levels in our present experiment were five to seven times the normal physiological postprandial concentration.

Our results clearly show that GLP-1 stimulated NHGU but had no effect on non-HGU. These studies created conditions that mimicked postprandial levels of insulin and glucose, conditions during which GLP-1 secretion is physiologically enhanced. The stimulation of glucose disposal was independent of pancreatic hormone secretion, as insulin and glucagon levels remained constant during GLP-1 infusion. In addition, our study also clearly demonstrated that the effects of GLP-1 were time dependent. Indeed, GLP-1 effects required over 90 min to be seen and even longer to be maximally effective (150-180 min). These results are in agreement with those of Nishizawa et al. (31), in which the highest dose of GLP-1 enhanced NHGU without increasing non-HGU. In that study, the possibility existed that the effect of GLP-1 on the liver was a consequence of increased hepatic blood flow, which was recorded concomitantly with this high dose of GLP-1. In the present study, the hepatic blood flows were not different between groups, and thus the possibility of this mechanism explaining an effect of GLP-1 on the liver is ruled out.

The insulin secretion-independent effect of GLP-1 on hepatic glucose uptake that we observed is consistent with the presence of specific GLP-1 receptors on the liver cells. Binding of GLP-1 to these receptors could initiate intracellular signaling pathways that could target kinases and/or factors involved in glucose uptake and glycogen synthesis. There are numerous reports of the presence of GLP-1 receptors in liver $(2,42)$, and in in vitro studies GLP-1 per se has been shown to increase glycogen synthesis in liver (2). However, the presence of such hepatic receptors remains controversial $(2,4,6,42)$. The utilization of a GLP-1 receptor antagonist such as exendin-(939) could be useful in future studies to clarify this mechanistic and important physiological issue. The presence of GLP-1 receptors in other glucose-consuming tissues, such as skeletal muscle and adipose tissue, has also been reported $(11,39,41)$, but the mechanism of action of GLP-1 in vitro appears to involve an enhancement of insulin's effects, since GLP-1 potentiates insulin effects on glucose transport or glycogen synthesis $(20,43,44)$. In view of the aforementioned data and the established presence of GLP-1 receptors on peripheral tissues such as skeletal muscle, it is surprising that we were unable to detect any stimulatory effect of GLP-1 on non-HGU in our study. This lack of response in peripheral tissues was not related to a decrease of glucose availability, as hyperglycemia was clamped at a fixed value by a peripheral glucose infusion. There are, nevertheless, several possible explanations. 1) GLP-1 has no effect on glucose utilization by peripheral tissues, this hypothesis being in accord with the few in vitro studies that were unable to detect a GLP-1 effect on glucose metabolism (13, 16); 2) GLP-1 indeed increased peripheral glucose utilization, but its effect was too small to be detected, given the power of our study; 3) the conditions of hyperglycemia and hyperinsulinemia had already maximally stimulated glucose uptake in peripheral tissues, and thus no further additional effect could be recorded; or 4) reciprocal cross talk between liver and nonhepatic tissues was such that, when NHGU increased, non-HGU was limited. The third hypothesis is unlikely, because McGuinness et al. (26) showed that the half-maximally effective plasma insulin level on glucose utilization by muscle and fat in $\operatorname{dog}$ is $80-100 \mu \mathrm{U} / \mathrm{ml}$, levels that are five times higher than the hyperinsulinemia created in our study. Regarding the last hypothesis, Galassetti et al. (14) performed a study in which the non-HGU and hindlimb glucose uptake were measured in the presence or absence of negative arterial-portal glucose gradient (i.e., to modulate the NHGU). To match the glucose delivery to peripheral tissues whatever the glucose infusion route, a pancreatic clamp was performed to maintain insulin, glucagon, and arterial glucose concentrations. This study (14) revealed that the stimulation of NHGU was associated with a decrease in glucose uptake by peripheral tissues by $40 \%$. A similar inhibition was evident upon assessing hindlimb (approximately two-thirds of skeletal muscle in the dog) glucose uptake, directly demonstrating that muscle was the main site of this inhibition. Such a mechanism, probably initiated within the hepatoportal region, was observed in the study of Nishizawa et al. (31) because GLP-1's enhancement of non-HGU disappeared when NHGU was stimulated. It remains unclear, however, why we observed in that study a stimulatory effect on non-HGU whereas we did not in the present study. In the first study (31), GLP-1 infusion raised arterial peptide levels to $\approx 400 \mathrm{pM}$, which was two times the concentrations we achieved in the present study. We cannot exclude the possibility that the short-term stimulation of nonHGU by GLP-1 requires high pharmacological levels to be effective. Another possible explanation for this discrepancy could be that, in our study, even with the short-term infusion of GLP-1, the hepatic glucose uptake and glycogen synthesis were already slightly enhanced (i.e., significant stimulation of glycogen synthesis). We may postulate that this small but already present hepatic stimulation by GLP-1 had already initiated a signal toward the peripheral tissues to prevent an increase of peripheral glucose utilization. Whether or not GLP-1 stimulation of non-HGU is dose dependent and/or directly dependent on the NHGU needs further investigation.

Several studies have been performed in vivo to assess the role of GLP-1 on glucose utilization independent of its effect on insulin secretion. The results, however, are divergent and conclusions hard to draw. Most of the clamp studies showing no insulin secretion-independent effect of GLP-1 were conducted under euglycemic conditions $(33,34)$, whereas when a positive effect was recorded the studies were performed in the presence of hyperglycemia $(35,40)$. These results suggest that the presence of hyperglycemia is required to fully express GLP-1 effects. The glucose-dependent effect of GLP-1 has largely been studied with regard to its effect on pancreatic $\beta$-cells. Indeed, it is now well established that GLP-1 enhances insulin secretion only in the presence of increased ambient glucose concentrations (1). Such a mechanism might also be postulated for the insulin secretion-independent effect of GLP-1 on glucose utilization. In addition, the present study 
showed that GLP-1 may have tissue-specific effects. We recorded an effect of GLP-1 on liver but not on nonhepatic tissues. Because of the limited contribution of the liver to whole body glucose utilization, whole body glucose $R_{d}$ and GIRs were not significantly increased during the GLP-1 infusion in the present study. The controversial results recorded in vivo regarding GLP-1's effect on glucose metabolism may arise from this tissue specificity, since a small increase in NHGU caused by GLP-1 may simply not be detected if only whole body glucose $R_{d}$ and GIRs are assessed.

Recent reports highlight the importance of the hepatoportal area in the physiological activity of $\operatorname{GLP}-1(3,5,21)$. For example, Nakabayashi et al. (30) reported that intraportal GLP-1 infusion at a physiological dose stimulated afferent vagal nerve activity in rats. This activation, in turn, stimulated efferent signaling in the pancreatic branch of the vagus nerve, suggesting a neural component of GLP-1's stimulation of insulin secretion. We hypothesized that the hepatoportal region may also be involved in the insulin secretion-independent effect of GLP-1. Our study clearly showed that GLP-1 infused intraportally did not further increase glucose utilization by the liver or peripheral tissues compared with a peripheral infusion of GLP-1. However, the dose of GLP-1 used may not have been optimal to identify the hepatoportal component of GLP-1 action. Indeed, the infusion rates used substantially increased portal GLP-1 concentrations even when infused peripherally. If the hepatoportal region is involved in the insulin secretionindependent effect of GLP-1, this rise in portal GLP-1 may have already been too great to allow us to distinguish portal from peripheral delivery. Further studies are thus needed to address the involvement of the hepatoportal region in the mechanism of action of GLP-1 on the liver or peripheral tissues.

In conclusion, GLP-1, at low pharmacological levels, increased NHGU and hepatic glycogen synthesis. This effect was time dependent and independent of insulin or glucagon secretion. The physiological relevance of our observation needs to be verified with lower doses of GLP-1 and plasma levels normally observed during a normal postprandial state. Nevertheless, our findings support a role for GLP-1 as a tool for the reduction of postprandial hyperglycemia in individuals with diabetes.

\section{ACKNOWLEDGMENTS}

Part of this work was given as an oral presentation at the American Diabetes Association 63rd Scientific Sessions, June 13-17, 2003, New Orleans, LA.

\section{GRANTS}

These studies were supported by National Institutes of Health, Grant R01 DK-43706 and Diabetes Research and Training Center Grant SP-60-AM20593.

\section{DISCLOSURES}

A. D. Charrington is on the research advisory board for Amylin and also receives a research grant for work related to exendin.

\section{REFERENCES}

1. Ahren B. Glucagon-like peptide-1 (GLP-1): a gut hormone of potential interest in the treatment of diabetes. Bioassays 20: 642-651, 1998.

2. Alcantara AI, Morales M, Delgado E, Lopez-Delgado MI, Clemente F, Luque MA, Malaisse WJ, Valverde I, and Villanueva-Penacarrillo. Exendin-4 agonist and exendin(9-39)amide antagonist of the GLP-1(7- 36)amide effects in liver and muscle. Arch Biochem Biophys 341: 1-7, 1997.

3. Balkan B and Li X. Portal GLP-1 administration in rats augments the insulin response to glucose via neuronal mechanisms. Am J Physiol Regul Integr Comp Physiol 279: R1449-R1454, 2000.

4. Blackmore PF, Mojsov S, Exton JH, and Habener JF. Absence of insulinotropic glucagon-like peptide-I(7-37) receptors on isolated rat liver hepatocytes. FEBS Lett 283: 7-10, 1991.

5. Burcelin R, Da Costa A, Drucker D, and Thorens B. Glucose competence of the hepatoportal vein sensor requires the presence of an activated glucagon-like peptide-1 receptor. Diabetes 50: 1720-1728, 2001.

6. Campos RV, Lee YC, and Drucker DJ. Divergent tissue-specific and developmental expression of receptors for glucagon and glucagon-like peptide-1 in the mouse. Endocrinology 134: 2156-2164, 1994.

7. Cherrington AD. Banting Lecture 1997. Control of glucose uptake and release by the liver in vivo. Diabetes 48: 1198-1214, 1999.

8. D'Alessio DA, Kahn SE, Leusner CR, and Ensinck JW. Glucagon-like peptide 1 enhances glucose tolerance both by stimulation of insulin release and by increasing insulin-independent glucose disposal. J Clin Invest 93: 2263-2266, 1994.

9. D'Alessio DA, Prigeon RL, and Ensinck JW. Enteral enhancement of glucose disposition by both insulin-dependent and insulin-independent processes. A physiological role of glucagon-like peptide I. Diabetes 44: 1433-1437, 1995.

10. Deacon CF, Plamboeck A, Moller S, and Holst JJ. GLP-1-(9-36) amide reduces blood glucose in anesthetized pigs by a mechanism that does not involve insulin secretion. Am J Physiol Endocrinol Metab 282: E873E879, 2002.

11. Delgado E, Luque MA, Alcantara A, Trapote MA, Clemente F, Galera C, Valverde I, and Villanueva-Penacarrillo ML. Glucagon-like peptide-1 binding to rat skeletal muscle. Peptides 16: 225-229, 1995.

12. Drucker DJ, Philippe J, Mojsov S, Chick WL, and Habener JF. Glucagon-like peptide I stimulates insulin gene expression and increases cyclic AMP levels in a rat islet cell line. Proc Natl Acad Sci USA 84: 3434-3438, 1987.

13. Furnsinn CEK and Waldhausl W. Failure of GLP-1(7-36) amide to affect glycogenesis in rat skeletal muscle. Diabetologia 38: 864-867, 1995.

14. Galassetti P, Shiota M, Zinker BA, Wasserman DH, and Cherrington AD. A negative arterial-portal venous glucose gradient decreases skeletal muscle glucose uptake. Am J Physiol Endocrinol Metab 275: E101-E111, 1998.

15. Gutniak M, Orskov C, Holst JJ, Ahren B, and Efendic S. Antidiabetogenic effect of glucagon-like peptide-1 (7-36)amide in normal subjects and patients with diabetes mellitus. N Engl J Med 326: 1316-1322, 1992.

16. Hansen BF, Jensen P, Nepper-Christensen E, and Skjølstrup B. Effects of glucagon-like peptide-1 (7-36)amide on insulin stimulated rat skeletal muscle glucose transport. Acta Diabetol 35: 101-103, 1998.

17. Holst JJ. Glucagon-like peptide-1, a gastrointestinal hormone with a pharmaceutical potential. Curr Med Chem 6: 1005-1017, 1999.

18. Holst JJ, Orskov C, Nielsen OV, and Schwartz TW. Truncated glucagon-like peptide I, an insulin-releasing hormone from the distal gut. FEBS Lett 211: 169-174, 1987.

19. Hsieh PS, Moore MC, Neal DW, Emshwiller M, and Cherrington AD. Rapid reversal of the effects of the portal signal under hyperinsulinemic conditions in the conscious dog. Am J Physiol Endocrinol Metab 276: E930-E937, 1999.

20. Idris I, Patiag D, Gray S, and Donnelly RU. Exendin-4 increases insulin sensitivity via a PI-3-kinase-dependent mechanism: contrasting effects of GLP-1. Biochem Pharmacol 63: 993-996, 2002.

21. Imeryuz N, Yegen BC, Bozkurt A, Villanueva-Peñacarrillo ML, and Ulusoy NB. Glucagon-like peptide-1 inhibits gastric emptying via vagal afferent-mediated central mechanisms. Am J Physiol Gastrointest Liver Physiol 273: G920-G927, 1997.

22. Kieffer TJ and Habener JF. The glucagon-like peptides. Endocr Rev 20: 876-913, 1999.

23. Kieffer TJ, McIntosh CH, and Pederson RA. Degradation of glucosedependent insulinotropic polypeptide and truncated glucagon-like peptide 1 in vitro and in vivo by dipeptidyl peptidase IV. Endocrinology 136: 3585-3596, 1995.

24. Luque MA, Gonzales N, Márquez L, Acitores A, Redondo A, Morales M, Valverde I, and Villanueva-Peñacarrillo ML. Glucagon-like peptide-1 (GLP-1) and glucose metabolism in human myocytes. J Endocrinol 173: 465-473, 2002. 
25. Massimino SP, McBurney MI, Field CJ, Thomson AB, Keelan M, Hayek MG, and Sunvold GD. Fermentable dietary fiber increases GLP-1 secretion and improves glucose homeostasis despite increased intestinal glucose transport capacity in healthy dogs. J Nutr 128: 1786-1793, 1998.

26. McGuinness OP, Myers SR, Neal D, and Cherrington AD. Chronic hyperinsulinemia decreases insulin action but not insulin sensitivity. Metabolism 39: 931-937, 1990.

27. Mentlein R, Gallwitz B, and Schmidt WE. Dipeptidyl-peptidase IV hydrolyses gastric inhibitory polypeptide, glucagon-like peptide-1(736)amide, peptide histidine methionine and is responsible for their degradation in human serum. Eur J Biochem 214: 829-835, 1993.

28. Mojsov S, Heinrich G, Wilson IB, Ravazzola M, Orci L, and Habener JF. Preproglucagon gene expression in pancreas and intestine diversifies at the level of post-translational processing. J Biol Chem 261: 1188011889, 1986

29. Myers SR, McGuinness OP, Neal DW, and Cherrington AD. Intraportal glucose delivery alters the relationship between net hepatic glucose uptake and the insulin concentration. J Clin Invest 87: 930-939, 1991.

30. Nakabayashi $\mathbf{H}$, Nishizawa $\mathbf{M}$, Nakagawa $\mathbf{A}$, Takeda $\mathbf{R}$, and Niijima A. Vagal hepatopancreatic reflex effect evoked by intraportal appearance of tGLP-1. Am J Physiol Endocrinol Metab 271: E808-E813, 1996.

31. Nishizawa M, Moore MC, Shiota M, Gustavson SM, Snead WL, Nea DW, and Cherrington AD. Effect of intraportal glucagon-like peptide-1 on glucose metabolism in conscious dogs. Am J Physiol Endocrinol Metab 284: E1027-E1036, 2003.

32. Nishizawa M, Nakabayashi H, Kawai K, Ito T, Kawakami S, Nakagawa $\mathbf{A}$, Niijima $\mathbf{A}$, and Uchida $\mathbf{K}$. The hepatic vagal reception of intraportal GLP-1 is via receptor different from the pancreatic GLP-1 receptor. J Auton Nerv Syst 80: 14-21, 2000.

33. Ørskov L, Holst JJ, Moller J, Ørskov C, Moller N, Alberti KGMM, and Schmitz O. GLP-1 does not acutely affect insulin sensitivity in healthy man. Diabetologia 39: 1227-1232, 1996.

34. Ryan AS, Egan JM, Habener JF, and Elahi D. Insulinotropic hormone glucagon-like peptide-1-(7-37) appears not to augment insulin-mediated glucose uptake in young men during euglycemia. J Clin Endocrinol Metab 83: 2399-2404, 1998
35. Sandhu H, Wiesenthal SR, MacDonald PE, McCall RH, Tchipashvill V, Rashid S, Satkunarajah M, Irwin DM, Shi ZQ, Brubaker PL, Wheeler MB, Vranic M, Efendic S, and Giacca A. Glucagon-like peptide 1 increases insulin sensitivity in depancreatized dogs. Diabetes 48 : 1045-1053, 1999.

36. Satake S, Moore MC, Converse M, Farmer B, Neal DW, and Cherrington AD. Direct and indirect effects of insulin on glucose uptake and storage by the liver. Diabetes 51: 1663-1671, 2002.

37. Theodorakis M, Carlson O, Michopoulos S, Doyle M, Juhaszova M, Petraki K, and Egan J. Glucose-dependent insulinotropic peptide and glucagon-like peptide 1 in impaired glucose tolerant states: role of duodenum (Abstract). Diabetes 52, Suppl 1: A77, 2003.

38. Thorens B. Expression cloning of the pancreatic beta cell receptor for the gluco-incretin hormone glucagon-like peptide 1. Proc Natl Acad Sci USA 89: 8641-8645, 1992

39. Valverde I, Merida E, Delgado E, Trapote MA, and VillanuevaPenacarrillo ML. Presence and characterization of glucagon-like peptide1(7-36) amide receptors in solubilized membranes of rat adipose tissue. Endocrinology 132: 75-79, 1993.

40. Vella A, Shah P, Basu R, Basu A, Holst JJ, and Rizza RA. Effect of glucagon-like peptide 1(7-36) amide on glucose effectiveness and insulin action in people with type 2 diabetes. Diabetes 49: 611-617, 2000.

41. Villanueva-Peñacarrillo ML, Alcántara AI, Clemente F, Delgado E, and Valverde I. Potent glycogenic effect of GLP-1(7-36)amide in rat skeletal muscle. Diabetologia 37: 1163-1166, 1994.

42. Villanueva-Peñacarrillo ML, Delgado E, Trapote MA, Alcãntara A, Clemente F, Luque MA, Perea A, and Valverde I. Glucagon-like peptide-1 binding to rat hepatic membranes. J Endocrinol 146: 183-189, 1995

43. Wang Y, Kole HK, Montrose-Rafizadeh C, Perfetti R, Bernier M, and Egan JM. Regulation of glucose transporters and hexose uptake in 3T3-L1 adipocytes: GLP-1 and insulin interactions. J Mol Endocrinol 19: 241-248, 1997.

44. Yang H, Egan JM, Wang Y, Moyes CD, Roth J, Montrose MH, and Montrose-Rafizadeh C. GLP-1 action in L6 myotubes is via a receptor different from the pancreatic GLP-1 receptor. Am J Physiol Cell Physiol 275: C675-C683, 1998. 